\title{
The historical development of three man-made reservoirs in a mining region: A story told by subfossil chironomids
}

\author{
Tímea CHAMUTIOVÁ, ${ }^{1 *}$ Ladislav HAMERLÍK, ${ }^{1,2}$ Katarzyna SZARLOWICZ, ${ }^{3}$ Radovan PIPIK, ${ }^{4}$ Dušan STAREK, \\ Ferdinand ŠPORKA, ${ }^{6}$ Marcela PřIDALOVÁ, ${ }^{1}$ Lucia SOCHULIAKOVÁ, ${ }^{1}$ Peter BITUŠÍK ${ }^{1}$
}

\begin{abstract}
${ }^{1}$ Matej Bel University, Faculty of Natural Sciences, Tajovskeho 40, 97401, Banská Bystrica, Slovakia; ${ }^{2}$ Institute of Geological Sciences, Polish Academy of Sciences, Twarda 51/55, 00-818, Warsaw, Poland; ${ }^{3}$ AGH University of Science and Technology, Faculty of Energy and Fuels, al. A. Mickiewicza 30, 30-059 Krakow, Poland; ${ }^{4}$ Earth Science Institute, Slovak Academy of Sciences, Dumbierska 1, 97401 Banska Bystrica, Slovakia; ${ }^{5}$ Earth Science Institute, Slovak Academy of Sciences, Dubravska cesta 9, 84005 Bratislava, Slovakia; ${ }^{6}$ Institute of Zoology, Slovak Academy of Sciences, Dubravska cesta 9, 84506, Bratislava, Slovakia
\end{abstract}

*Corresponding author: timea.chamutiova@umb.sk

\begin{abstract}
Chironomid stratigraphic changes were studied in three man-made reservoirs situated in a region intensely used for mining in the past (Banska Stiavnica, Central Europe). The reservoirs were built in the first half of the $18^{\text {th }}$ century and are remnants of a former hydro-energetic system that provided water for mining and smelting facilities until the 1920s. Sediment cores spanning the last 170 200 years were sampled and dated. A total of 58 taxa were identified, with the most common taxa being Cladotanytarsus mancus-type, Polypedilum nubeculosum-type, Procladius spp. and Tanytarsus spp. Changes in the subfossil assemblages suggest that all reservoirs followed similar developmental trends. The low number of chironomid remains and the prevalence of littoral and rheophilic taxa characterize the initial phase, with severe water level fluctuations and unproductive conditions. A dramatic shift in both the qualitative and quantitative structure of the chironomid assemblages accompanied the decline of mining activities in the region. The second period of reservoir development was linked to changes in sediment composition and an increase of sediment organic content. In this phase, chironomids indicate nutrient enrichment, and the development of a hypoxic profundal zone, and complex littoral habitats. Since the 1970 s, changes in the assemblage structure indicate a reduction in the profundal fauna and an increasing importance of the littoral taxa. Despite the significantly different usage of the reservoirs after the mining phase (recreation and angling $v s$ drinking water supply) the changes in chironomid assemblages were fairly similar and indicated nearly identical developmental trajectories.
\end{abstract}

Key words: Chironomidae; palaeolimnology; anthropogenic impact; eutrophication; water-level fluctuations; Slovakia.

Received: February 2018. Accepted: July 2018.

This paper was presented at the 20 International Symposium on Chironomidae, Trento, Italy, 2-8 July 2017.

Session: Palaeolimnology.

\section{INTRODUCTION}

Mining and metallurgy can cause great devastation of both terrestrial and aquatic environments at different scales. The large quantities of wastes produced by mines and smelters cause pollution of the air, soil, surface waters, and groundwater (Rybicka, 1996). Moreover, mining frequently alters landscapes (Bell and Donnelly, 2006), and this can provide valuable historical evidence of such past activities. This is the case of a unique, dramatically human-modified landscape around Banska Stiavnica (Central Slovakia), which was declared a UNESCO World Heritage Site in 1993.

Hundreds of years of ore mining reshaped the landscape of the region and have left a legacy of various surface and subsurface structures. The remain of a former hydroenergetic system is among the most remarkable and impressive of these structures. This system, comparable only with the German Upper Harz Water Management System (Teicke and Tonn, 2006), was completed during the largest mining expansion between the beginning of the $18^{\text {th }}$ and the first half of the $19^{\text {th }}$ centuries. At that time it consisted of 54 reservoirs connected with a network of more than $100 \mathrm{~km}$ of channels and galleries. Water from this system provided energy for operating mining machines, ore cleaning facilities and smelting (Novák, 1977).

At the present time, 24 reservoirs are preserved and serve mostly for recreation and angling (Lichner et al., 1999). Since the region is poor in natural waterbodies, these reservoirs, which maintain a great variety of aquatic plants and animals, can be considered "hot spots" for regional biodiversity with high conservation value (Bitušík et al., 2007). Moreover, they contain limnic deposits that can be exploited as a unique archive for historical reconstructions pertaining to the reservoirs and surrounding landscape. 
Here we present a palaeolimnological study of three man-made water reservoirs that were built in the first half of the $18^{\text {th }}$ century and were among the largest in the former hydro-energetic system, but which later developed differently. One of the reservoirs has become a source of drinking water with a protected watershed, while the other two have become centres for recreation with the urbanization of the surrounding landscape. From each reservoir we analysed a dated sediment sequence for lithology, organic matter and chironomid remains. Using chironomids as indicators of past environmental changes (e.g Smol et al., 2001; Brodersen and Quinlan, 2006; Brooks et al., 2007) we obtained a picture of changing limnological conditions in the reservoirs.

\section{METHODS}

\section{Lake selection and study sites}

Three reservoirs situated in the Banska Stiavnica region, intensely used for mining in the past, were selected for this study. The reservoirs Velka Richnava (RICH), Rozgrund (ROZ) and Vindsachta (VIND) are located in the Stiavnické vrchy Mountains (Western Carpathians), which were formed during several stages of andesitic and rhyolitic volcanism in the Middle and Late Miocene (Chernyshev et al., 2013).

The bedrock of VIND and RICH and their surroundings consists of pyroxene and amphibole-pyroxene andesite with accessory biotite, quartz and garnet altered by successive hydrothermal activity. ROZ is surrounded by more heterogeneous bedrock comprising mineralogical varieties of andesite and diorite, and hydrothermally altered veins. The bedrock at all three sites is covered by deluvial deposits, mostly loamy-stony and stony screes (Konečný et al., 1998; Chernyshev et al., 2013).

The reservoirs are located in an open mountainous landscape with a mosaic of mixed forests and grasslands. The landscape surrounding RICH and VIND is partially urbanised. RICH and VIND belong to the same reservoir group and were interconnected via a channel; $\mathrm{ROZ}$ is about $20 \mathrm{~km}$ away from them (Fig. 1). Climate in the area is slightly warm and humid, with a mean annual air temperature $\sim 7.4^{\circ} \mathrm{C}(600 \mathrm{~m}$ asl), and a mean annual precipitation of $830 \mathrm{~mm}$ with $73.6 \%$ relative humidity (Križáni et al., 2007).

All of the reservoirs are deepest at the dams and are thermally stratified in summer. Fish are present in all three lakes; while carp prevail in RICH and VIND, the fish stock in ROZ is dominated by trout. A more detailed description of the sites studied is given in Tab. 1 .

\section{Sediment coring and sampling}

Long sediment cores were taken from the deepest parts of the reservoirs from a floating platform using a UWITEC

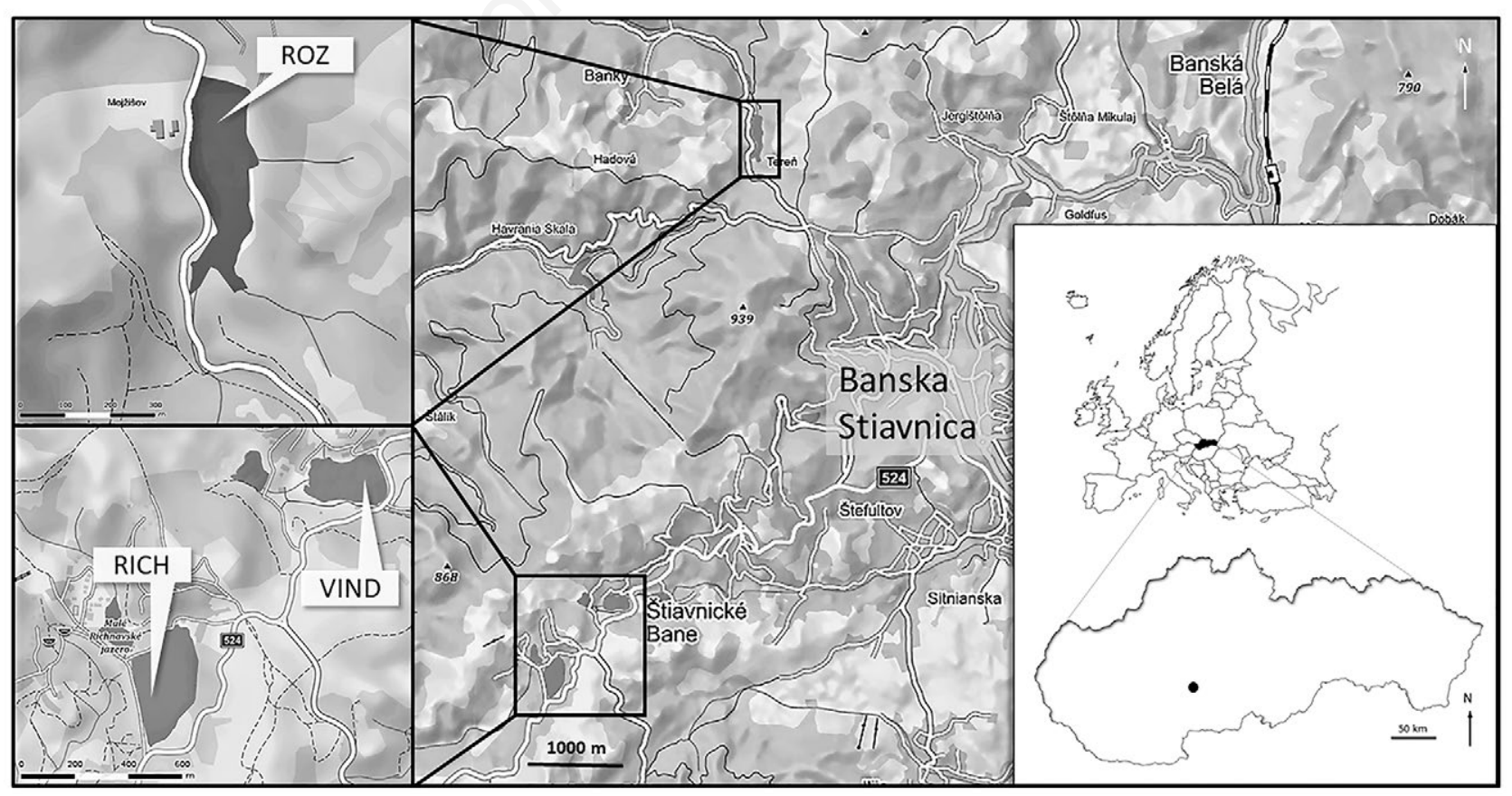

Fig. 1. Location of the reservoirs studied in the Banska Stiavnica mining region (Central Slovakia). Labels indicate the sampling location in each reservoir. 
Niederreiter $60(\varnothing 6.0 \mathrm{~cm})$ hydraulic coring system. Coring of RICH took place on September 2015, while ROZ and VIND were cored on May 2016. From each reservoir, two sediment cores were obtained (core length: RICH -1.84 , $1.10 \mathrm{~m}, \mathrm{ROZ}-4.20,3.53 \mathrm{~m}$, and VIND - 1.2, $1.03 \mathrm{~m}$ ). Only the longer cores were used for analysis.

In the laboratory the sediment cores were cut longitudinally, opened, photographed and described lithologically. The cores were subsampled into $\sim 1 \mathrm{~cm}$ sections and refrigerated in plastic zip-bags for later analysis.

\section{Laboratory}

Dating. The sediment chronologies were developed from ${ }^{210} \mathrm{~Pb}$ using the CRS model and from ${ }^{137} \mathrm{Cs}$ profiles. ${ }^{210} \mathrm{~Pb}$ concentrations were determined via two ${ }^{210} \mathrm{Po}$ depositions. ${ }^{137} \mathrm{Cs}$ measurements were performed using an HPGe detector. For more details concerning chronological methods see Szarlowicz et al. (2013, 2014, 2018).

Organic matter. The amount of organic matter and carbonate content was determined as loss-on-ignition (LOI) and expressed as the percentage of weight loss after combustion at $550{ }^{\circ} \mathrm{C}$ for $4 \mathrm{~h}$ (Heiri et al., 2001).

Chironomid analysis. The number of samples analysed for chironomid remains varied from 22 (VIND) and 27 (RICH) to 30 (ROZ), with the samples being evenly distributed along the cores. The selected sediment samples were first washed with distilled water on a $175 \mu \mathrm{m}$-mesh sieve to remove coarse-grained sediments, and subsequently with on a $50 \mu \mathrm{m}$-mesh sieve to capture small head capsules. When possible, 50 chironomid head capsules were collected from each sample using a stereomicroscope at 7-40× magnification. Head capsules were mounted on slides using Berlese solution. Taxonomic identification using 100-400× magnification was based on Brooks et al. (2007) and Andersen et al. (2013).

Hierarchical classification was conducted to distinguish the main zones. For this purpose, square root transformed relative abundances of chironomid data were used in a stratigraphically constrained square cluster analysis (CONISS) using the Cavalli-Sforza and Edwards chord distance measure with TILIA version 1.7.16 (Grimm, 1987). Stratigraphic diagrams were constructed using C2 software version 1.7.7. (Juggins, 2007), and only taxa representing $>5 \%$ of total abundance in each layer are shown.

\section{RESULTS}

\section{Chronology}

The $171 \mathrm{~cm}$ long sediment sequence from RICH was deposited over the last ca 174 years (Fig. S1). The deepest sediment layers recorded in $\mathrm{ROZ}(\sim 401 \mathrm{~cm})$ were deposited around the beginning of the 1825s (Fig. S2). In VIND, $82 \mathrm{~cm}$ of sediment represents the last 200 year (Fig. $\mathrm{S} 3)$. In the majority of samples, the ${ }^{137} \mathrm{Cs}$ radioactivity was below the limit of detection. Nevertheless, an attempt was made and we confirmed the age of the sediments using ${ }^{137} \mathrm{Cs}$ studies. The sediment layer, characterized by a distinct ${ }^{137} \mathrm{Cs}$ peak was attributed to the nuclear weapons tests (1950/1960). Also the Chernobyl accident (1986) introduced a significant spike of ${ }^{137} \mathrm{Cs}$ radioactivity in a large area of Europe. In RICH, the higher radioactivity in the samples 10-11 cm $\left(11 \pm 3\right.$ Bq. $\left.\mathrm{kg}^{-1}\right), 40-41 \mathrm{~cm}$ and 50$51 \mathrm{~cm}\left(\sim 6 \mathrm{~Bq} \cdot \mathrm{kg}^{-1}\right)$ correspond well to the timing of the mentioned events. The ${ }^{137} \mathrm{Cs}$ radioactivity in VIND reservoir was present at $26 \mathrm{~cm}$ in the core in the range of $202.0 \pm 6.3$ to $41.5 \pm 3.8 \mathrm{~Bq} \cdot \mathrm{kg}^{-1}$. Here, the best match has been found, where the higher radioactivity of ${ }^{137} \mathrm{Cs}$ between 11 and $16 \mathrm{~cm}$ layer can be ascribed to the Chernobyl accident. The presence of ${ }^{137} \mathrm{Cs}$ at $26 \mathrm{~cm}$ can be associated with the nuclear weapon tests. A slightly different situation was detected in ROZ, where ${ }^{137} \mathrm{Cs}$ was determined only in the top $3 \mathrm{~cm}$ layer and at the depth 31 $\mathrm{cm}\left(128 \pm 4.5 \mathrm{~Bq} \cdot \mathrm{kg}^{-1}\right)$. The ${ }^{137} \mathrm{Cs}$ peak occurring at $141 \mathrm{~cm}$

Tab. 1. Comparison of the study sites (Data from Lichner et al., 1999; Kubinský et al., 2013; Fuska et al., 2015).

\begin{tabular}{|c|c|c|c|}
\hline Reservoir & Velka Richnava & Vindsachta & Rozgrund \\
\hline Coordinates & $\mathrm{N} 48^{\circ} 25^{\prime} 37^{\prime \prime} \mathrm{E} 18^{\circ} 50^{\prime} 46^{\prime \prime}$ & $\mathrm{N} 48^{\circ} 26^{\prime} 03^{\prime \prime}$ E $18^{\circ} 51^{\prime} 22^{\prime \prime}$ & N 4828'39"'E $18^{\circ} 52^{\prime} 32^{\prime \prime}$ \\
\hline Year of construction & 1740 & 1715 & 1743 \\
\hline Dam length (m) & 320.2 & 237.1 & 125.0 \\
\hline Altitude (m asl) & 725 & 688 & 703 \\
\hline Max depth (m) & 19.5 & 12.7 & 20.9 \\
\hline Volume $\left(\mathrm{m}^{3}\right)$ & $\sim 666,000$ & $\sim 285,000$ & $\sim 575,000$ \\
\hline Area $\left(\mathrm{m}^{2}\right)$ & 82,830 & 46,540 & 54,350 \\
\hline Shoreline length (m) & 1,110 & 854 & 1,258 \\
\hline Shoreline development ${ }^{*}$ & 1.09 & 1.12 & 1.53 \\
\hline
\end{tabular}


most likely corresponds with the nuclear weapons test, but the number of counts was too small to quantify.

\section{Lithology}

The $184 \mathrm{~cm}$ long RICH core penetrated through the entire sedimentary infill. It starts with weathered purple andesite representing the original bedrock on which a grey mixture of gravel, sand, and clay with wood remnants was deposited. The limnic deposition starts from $169 \mathrm{~cm}$ with grey and black clay sediment. Above $166 \mathrm{~cm}$, dynamic deposition is reflected in a $70 \mathrm{~cm}$ thick layer of coarsegrained sand and gravel, and erosive contacts at $166 \mathrm{~cm}$ and $125.5 \mathrm{~cm}$. The grey silt and sand deposition starting from $96.5 \mathrm{~cm}$ terminated in the deposition of the black, bioturbated silt. Discharge of the reservoir in 2014 caused drying of the surface deposits and propagation of desiccation cracks down to $44 \mathrm{~cm}$ depth.

The VIND core $(117 \mathrm{~cm})$ captured the entire sedimentary record. The lithological profile begins with loamy-stony green and grey deluvial deposits with clasts of weathered andesite. There is a sharp boundary between the deluvial deposits and limnic infill at $106.5 \mathrm{~cm}$. Above this boundary, grey limnic silt is intercalated by up to 4 $\mathrm{cm}$ thick fine-grained sand layers. Grey silt continuously changed to dark grey silt with bioturbation traces. In the upper part of the profile, between 2 and $50 \mathrm{~cm}$, the dark silt is mixed with dispersed angular grains and intercalated with fine-grained gravel. The sedimentation finished with a thin layer of black gyttja $(0-2 \mathrm{~cm})$.

The ROZ core $(414 \mathrm{~cm})$ begins with dark brown to purple loamy-stony deluvial deposit. The boundary between the deluvial deposit and the limnic sedimentary infill is not sharp and was put tentatively to $408 \mathrm{~cm}$. The highly dynamic sedimentation lead to the deposition of liquefied fine-grained grey gravel with wood particles and reflects the erosion of the deluvial deposits. Fine-grained sand and laminated silt with light and dark grey laminae of 2-10 $\mathrm{mm}$ dominate from 340 to $34 \mathrm{~cm}$. They are disturbed by sand intervals rich in organic matter and plant fragments, needles, and wood particles. Liquefied dark fine-grained gravel to coarse-grained andesite sand with plant detritus occurs between 117 and $129 \mathrm{~cm}$. Sedimentation terminates in the deposition of black, bioturbated gyttja $(10-34 \mathrm{~cm})$ and gravel with occasional pebbles $(0-10 \mathrm{~cm})$.

\section{Chironomid analysis}

A total of 2511 chironomid head capsules were identified, belonging to 58 taxa from 5 subfamilies. The complete list of found chironomid taxa is shown in Tab. 2. RICH yielded 1,040 head capsules (40 taxa), ROZ 802 head capsules (42 taxa), and VIND 669 head capsules (35 taxa). The number of remains per sample varied from 3 to 80 (RICH), 0 to 74 (ROZ), and 0 to 72 (VIND).
The most abundant taxa, occurring in all studied reservoirs, were Cladotanytarsus mancus-type, Polypedilum nubeculosum-type, Procladius spp. and Tanytarsus spp. In RICH, C. mancus-type (22.2\%), P. nubeculosum-type (15\%), Tanytarsus spp. (9.4\%), Procladius spp. (9\%), and Micropsectra spp. (7.2\%) were the most common, with an overall abundance of more than $60 \%$. The most common taxa occurring in nearly all ROZ samples were C. mancus-type (17.8\%), P. nubeculosumtype (10.8\%), Procladius spp. (9.6\%), Micropsectra spp. (9.2\%) and C. plumosus-type (7.7\%). These taxa made up more than $55 \%$ of the total abundance. The most frequent taxa in VIND, occurring in more than half of the samples, were Tanytarsus spp. (24.4\%), Procladius spp. (23.5\%) and P. nubeculosum-type (6.9\%).

The cluster analysis divided the chironomid assemblages into significant zones.

In RICH, three zones were identified (Fig. 2):

The bottom zone, RICH-Z1 (171-93 cm; 1841-1933 $\mathrm{AD}$ ), was characterized by a low number of chironomid head capsules (3-19).

RICH-Z2 (92-20 cm; 1933-1974 AD) showed a significant increase both in abundance and taxa richness. C. mancus-type, P. nubeculosum-type, C. plumosus-type and Dicrotendipes nervosus-type dominated in this zone. Harnischia spp. and Nanocladius rectinervis-type appeared in this zone for the first time and disappeared in the subsequent zone.

RICH-Z3 (20-0 cm; 1974-2015 AD) was marked by a marked increase of new taxa, such as Microtendipes pedellus-type, Dicrotendipes notatus-type, Polypedilum sordens-type, Ablabesmyia spp., and Paratanytarsus spp. The relative abundance of previously dominant taxa $(C$. plumosus-type, D. nervosus-type, and Micropsectra spp.) slightly decreased.

Four zones were recognized in ROZ (Fig. 3):

ROZ-Z1 (409-296 cm; 1825-1915 AD) was characterised by a low number of chironomid head capsules (0-11) and taxa (0-4) per sample.

In ROZ-Z2 (296-229 cm; 1915-1930 AD) there was an unusually high proportion of rheophilic taxa (Paratrichocladius sp., Eukiefferiella sp. and Tvetenia bavarica-type); however, the zone was dominated by taxa frequent throughout the core. A decrease of rheophilic taxa and a dramatic increase in head capsule number and diversity was typical for ROZ-Z3 (229-60 cm; 1930-1970 AD). The most abundant taxa were C. mancus-type, $P$. nubeculosum-type, D. nervosus-type, Micropsecra spp., Procladius spp. and C. plumosus-type. Some rheophilic taxa (Rheocricotopus effusus-type, and Diamesa sp.), Harnischia spp., P. bathophila-type and Cricotopus intersectus-type occurred in this zone for the first time.

ROZ-Z4 (60-0 cm; 1970-2013) was marked by a significant increase of new taxa (M. pedellus-type, 
Tab. 2. Complete list of subfossil chironomid taxa found in the investigated sediment cores, indicating presence $(+)$ and absence $(-)$ in each reservoir.

Ablabesmyia spp.

Macropelopia sp.

Procladius spp.

Psectrotanypus varius (Fabricius, 1787)

Diamesa sp.

Potthastia cf. gaedii (Meigen, 1838)

Prodiamesa olivacea (Meigen, 1818)

Brillia bifida (Kieffer, 1909)

Chaetocladius spp.

Corynoneura spp.

Cricotopus bicinctus-type

Cricotopus cylindraceus-type

Cricotopus intersectus-type

Cricotopus obnixus-type

Cricotopus (Isocladius) type-C

Cricotopus sp.

Eukiefferiella sp.

Limnophyes sp.

Metriocnemus sp.

Nanocladius rectinervis-type

Orthocladius spp.

Paracladius conversus (Walker, 1856)

Parakiefferiella bathophila-type

Parametriocnemus sp.

Paratrichocladius sp.

Paratrissocladius excerptus (Walker, 1856)

Psectrocladius barbatipes-type

Psectrocladius spp.

Rheocricotopus effusus-type

Smittia/Parasmittia sp.

Synorthocladius semivirens (Kieffer, 1909)

Tvetenia bavarica-type

Chironomus anthracinus-type

Chironomus plumosus-type

Cladopelma laccophila-type

Cladopelma lateralis-type

Cryptochironomus spp.

Cryptotendipes sp.

Dicrotendipes nervosus-type

Dicrotendipes notatus-type

Einfeldia dissidens-type

Endochironomus albipennis-type

Endochironomus tendens-type

Glyptotendipes spp.

Harnischia spp.

Microchironomus sp.

Microtendipes pedellus-type

Parachironomus varus-type

Paracladopelma spp.

Paratendipes albimanus-type

Polypedilum nubeculosum-type

Polypedilum sordens-type

Sergentia coracina-type

Cladotanytarsus mancus-type

Micropsectra spp.

Paratanytarsus spp.

Stempellina sp.

Tanytarsus spp.

Number of taxa

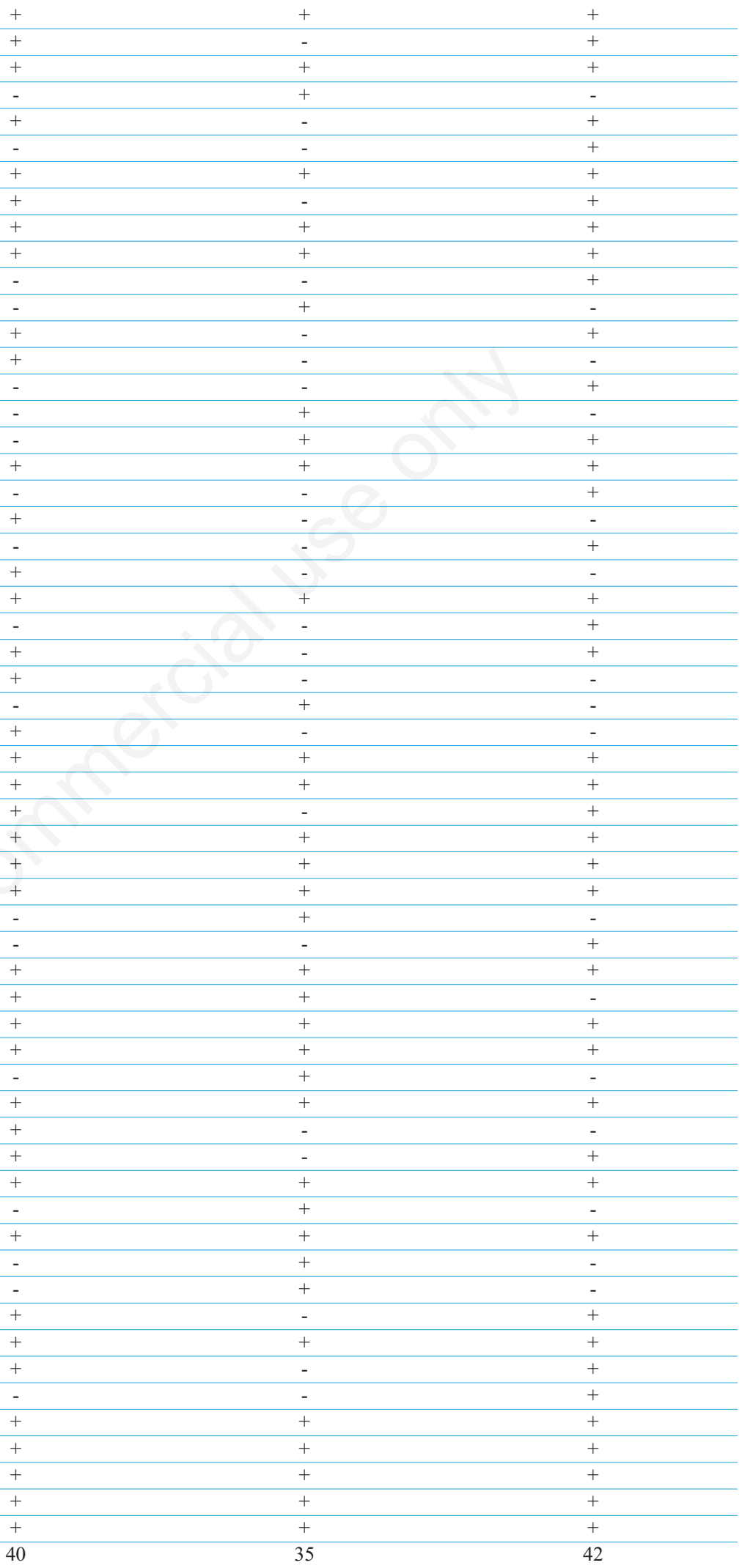



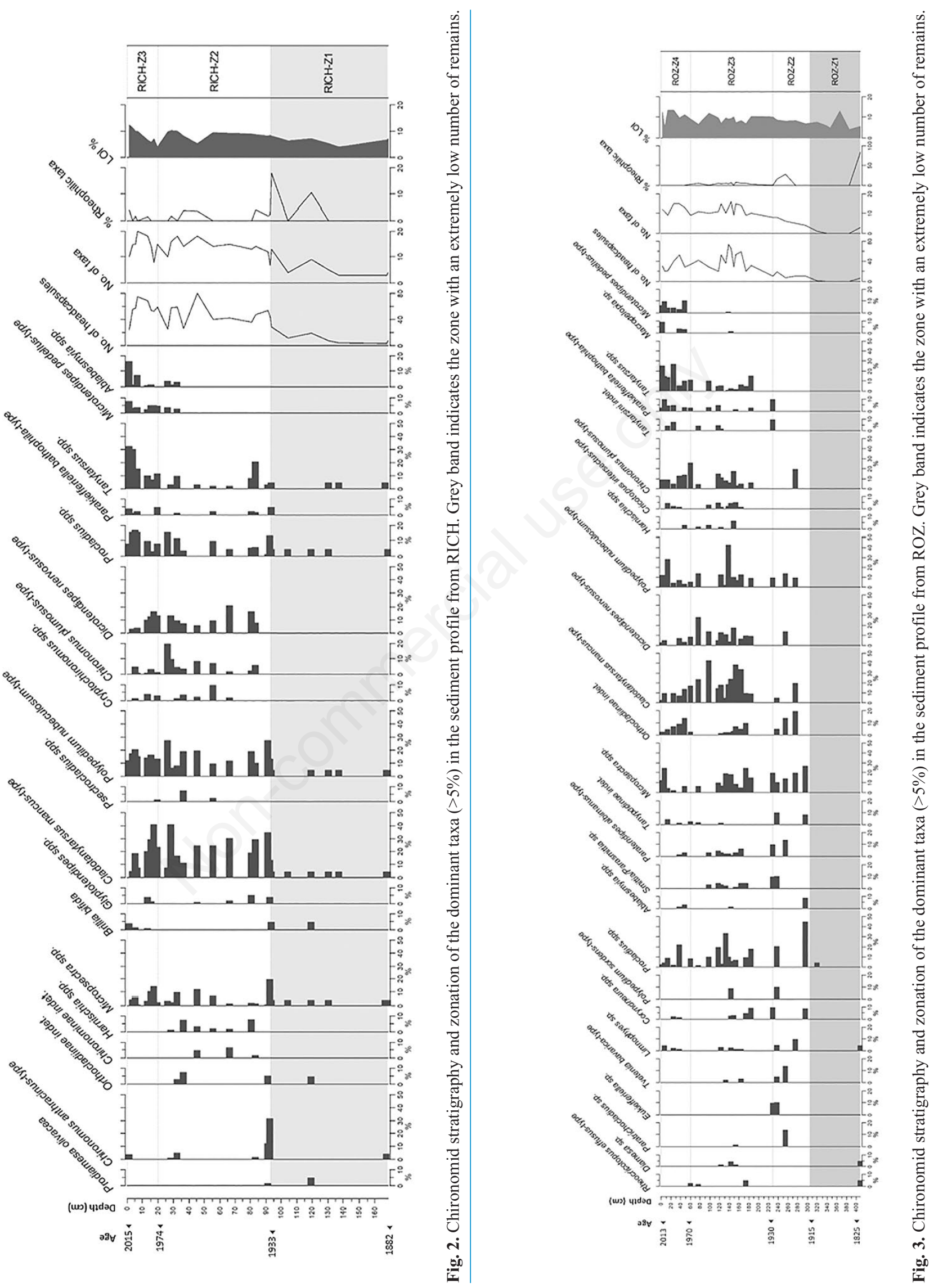
Macropelopia sp., and Ablabesmyia spp.). The relative abundance of some dominant taxa increased $(P$. nubeculosum-type, C. plumosus-type and Micropsectra spp.) and the abundance of $C$. mancus-type decreased.

The chironomid assemblages of VIND were divided into three zones (Fig. 4):

VIND-Z1 (106-70 cm; <1816-1816 AD) contained an extremely low number of chironomid head capsules (0-7) and taxa (0-5).

In VIND-Z2 (70-24 cm; 1816-1965 AD) the number of taxa and head capsules gradually increased. Procladius spp. and Tanytarsus spp. predominated, and taxa such as Cricotopus cylindraceus-type, Cricotopus sp., R. effusus-type, Psectrocladius barbatipes-type and Eukiefferiella sp. occurred just in this zone and then disappeared in the surface sediment samples. The upper part of this zone was remarkable in having the first occurrence of $M$. pedellus-type, which also remained in the following zone.

The noteworthy features of VIND-Z3 $(24-0 \mathrm{~cm}$; 1965-2013 AD), were high diversity and the persisting dominance of Procladius spp., Tanytarsus spp. and $P$. nubeculosum-type. This zone was characterized by significant increases in new taxa such as Ablabesmyia spp., Microchironomus sp., Prodiamesa olivacea, Psectrotanypus varius and T. bavarica-type.

\section{DISCUSSION}

The lithological profiles of all three reservoirs began with the original bedrock (andesite) and the oldest dated sediment sequences in RICH and ROZ $\approx \approx 1841$ and 1825 $\mathrm{AD}$, respectively) lie directly on this substrate. In VIND the oldest dated sediment layer (estimated to $\approx 1816$ ) was situated at 81-82 $\mathrm{cm}$ with an additional ca. $20 \mathrm{~cm}$ of undated, sediments beneath (see Supplementary Material for a detailed lithological description). Given the relatively stable sedimentation rate, the time of deposition of the oldest recorded layers was estimated to $\sim 1760$ AD. Considering the documented age of the reservoirs, it is clear that the initial ca. 50 (VIND) and 100 years (RICH, ROZ) of the reservoir history are missing from the records.

There is very little historical evidence of the past manipulations of these reservoirs, but we assume that the missing sediments may have been washed out by strong currents when the reservoirs were drawn down, and/ or could have been removed to increase retention capacity or during reconstruction of the dams (Jakab, 2003; Kubinský et al., 2013).

Unfortunately, because the oldest sediments are missing, the initial phase immediately following reservoir formation (Baxter, 1977), usually

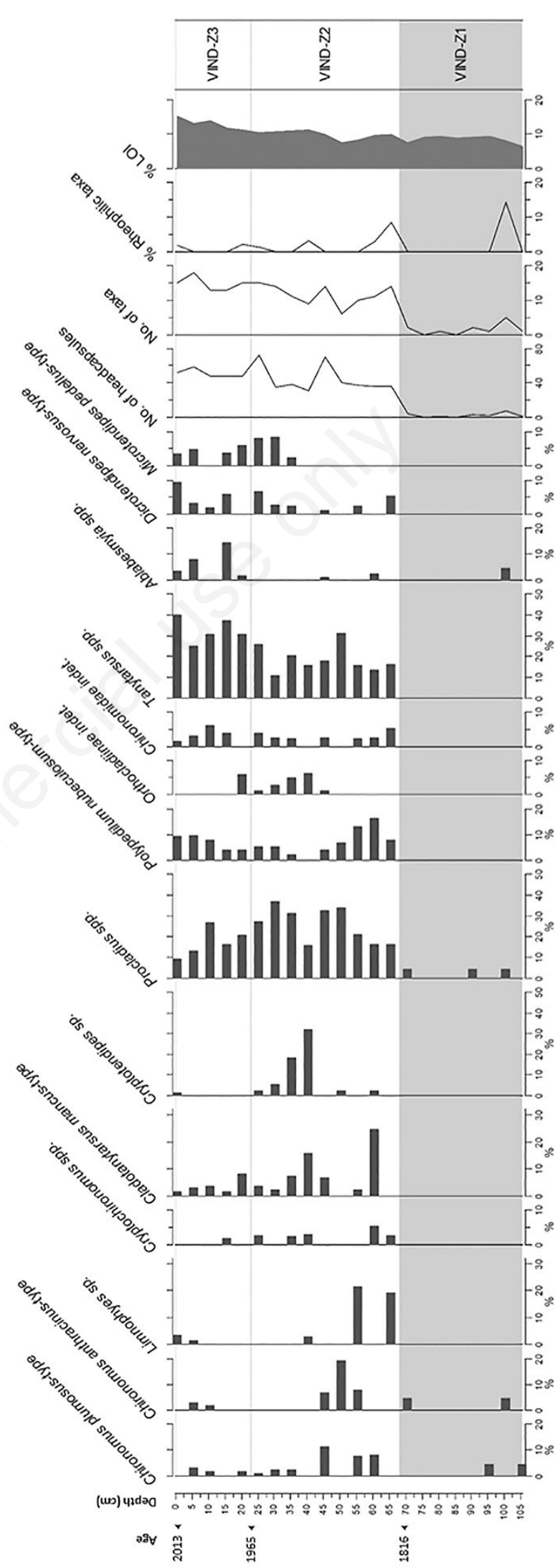


characterized by a high abundance and biomass of chironomid larvae (Armitage, 1983; Krzyzanek, 1986), was not included in our stratigraphic records.

Based on the number of chironomid remains in the sediment, two major historical phases were identified. The first, initial phase, marked by extremely poor number of remains, represents the period of intensive use of the reservoirs as water-energy source (Figs. 2-4, grey band). The second phase, indicated by the abrupt and significant increase of the abundance of remains, represents the mature period of reservoirs with stabilized hydrological conditions as a consequence of complete filling up the reservoirs and the cease of dramatic water-level oscillations. Within the mature phase, the chironomid assemblage changes indicated additional zones (two in RICH, VIND and three in ROZ).

\section{Initial phase of the reservoirs: Hydraulic power sources}

This phase coincides with the period of the intense water use for energy purposes with the reservoirs operating under a dynamic regime. Major water level changes were frequent, and consequently large parts of the reservoir bottom were uncovered for longer periods. This resulted in significant erosion, sediment transport from surrounding slopes and shorelines, and the deposition of fine-grained gravels containing weathered andesite and wood remains.

Although the dearth of chironomid remains in this part of the stratigraphic record does not facilitate reliable interpretation of the chironomid stratigraphies in terms of relative abundance, the appearance of taxa with welldefined ecological requirements combined with sediment properties provides some indication of environmental conditions at this time. Prevalence of littoral and rheophilic taxa indicates shallow, well oxygenated reservoirs without a profundal -community, especially at RICH and ROZ. The taxonomic composition in the oldest parts of the VIND stratigraphic record indicates a higher water level, an interpretation also supported by the slowest sediment accumulation rate $\left(0.41 \mathrm{~cm}\right.$ year ${ }^{-1}$ on average).

Chironomid communities were likely influenced by water level fluctuations both directly and indirectly. The vertical up- or downward movements of the water levels dramatically limited the living space at the periphery of the reservoirs and altered the sediment characteristics. The relatively high sedimentation rates and changes in sediment composition suggest a dynamic environment with rapid sedimentation (1.2 and $2.7 \mathrm{~cm}^{\text {year-1 }}{ }^{-1}$ on average) of inorganic material eroded from the exposed shoreline. The higher erosion rate in ROZ may be associated with the more intense shoreline development, as compared to VIND and $\mathrm{RICH}$. We assume that mineral substrates without macrophytes dominated the bottom during this phase. The low organic content in these sediments suggests low primary production and food supply. The food scarcity may have been further exacerbated by the introduction of carp to the reservoirs beginning in the 1810s (Lichner et al., 1999). With a high density of fish, low head capsule concentrations and low chironomid diversity would be expected (Langdon et al., 2010).

\section{Mature phase of the reservoirs: Stable hydro-morphology, differing management}

The upper zones of all sediment records portray obvious changes in terms of both the qualitative and quantitative structures of the chironomid assemblages. This shift generally corresponds to the documented decline of mining activities in the region in the 1920s, as the reservoirs gradually lost their original function as energy sources (Lichner et al., 1999). RICH and ROZ were allowed to completely fill with water, so extreme water level oscillations ceased. This change is dated between the 1930s and 1940s. As mentioned above, the water level of VIND was maintained at a higher level beginning earlier in the $19^{\text {th }}$ century and it was completely filled by the end of the $1850 \mathrm{~s}$.

In RICH the beginning of the stabilized period corresponds to the first appearance and high proportional abundance of C. anthracinus-type and its replacement by a superior competitor, C. plumosus-type, under the more stable conditions (Matěna, 1990). In contrast, at VIND, C. anthracinus-type and C. plumosus-type were present in the assemblage from the beginning.

Concerning ROZ, a high proportion of rheophilic and semi-terrestrial taxa were found in the assemblages during the decades preceding development of the lacustrine chironomid fauna (zone ROZ-Z2). We assume that water levels during this period were generally low and thus streams flowing across the uncovered and exposed reservoir bottom could have supported rheophilic communities as reflected in the sediment sequence.

The rise in water levels and more stable hydrological conditions are evidenced by the reduction of shoreline erosion in RICH and ROZ. The longer water residence time reduced losses of nutrients and plankton (Campbell et al., 1998) and increased in pelagic primary production. The presence of C. plumosus-type throughout this period indicates that the profundal zone received greater quantities of fresh phytoplankton material (Prat et al., 1992). Together with the presence of Procladius larvae this indicates eutrophic conditions (Brodersen and Lindegaard, 1999) connected to oxygen depletion during periods of stagnation. The higher trophic status of the reservoirs is reflected by the dominance of P. nubeculosum-type and C. mancus-type, both being considered indicators of eutrophy (Langdon et al., 2006).

The diverse littoral fauna suggests a complex littoral 
habitat, comprised of a mosaic of submergent and emergent macrophytes, and exposed bottom patches of both coarse inorganic substrates, detrital particulate organic matter and soft organic sediments. Larvae of e.g., Ablabesmyia, Dicrotendipes, Glyptotendipes, Endochironomus and Cricotopus are associated with macrophytes mainly as a substratum, and to a lesser extent as a food source (Moller Pillot, 2009). P. nubeculosumtype together with Tanytarsus, C. mancus-type, Micropsectra, P. bathophila and Cryptotendipes can be considered inhabitants of soft sediments, while the predatory larvae of Cryptochironomus and Harnischia prefer rather sandy bottoms with organic material (Moller Pillot, 2009 and citations therein).

Since the 1970s, an obvious increase in chironomid diversity has been accompanied by the first appearances of some minor taxa in all reservoirs. The marked appearance of $M$. pedellus-type at the top of the stratigraphic records coincides with declines in C. plumosus-type and C. mancus-type, and increased abundance of $P$. nubeculosum-type, Micropsectra spp. and Tanytarsus spp., suggesting a reduction of the profundal fauna (the decline of Procladius spp. is clear in ROZ and VIND) and the dominance of littoral taxa.

Generally, the chironomid succession and sediment organic content indicate a fairly similar ontogeny for the reservoirs. The common developmental trajectories point toward a further development of littoral vegetation, an increase of habitat complexity and more productive conditions. Despite the significantly different usage and management of the reservoirs after the mining phase, signs of human-induced eutrophication in RICH and VIND are not clear. The simultaneous marked decrease of profundal assemblages in all three reservoirs is most likely related to depleted profundal oxygen conditions that affected at least some parts of the bottom. This could have affected the profundal community directly by limiting its density. Moreover, under anoxic conditions nutrients are released from sediments and sustain rates of photosynthetic productivity. Such higher productivity could have also supported the further development of littoral macrophyte growth and related littoral chironomid communities.

\section{CONCLUSIONS}

Subfossil chironomid assemblages from the sediments of three reservoirs of known age were studied. All reservoirs shared an initial intense mining history followed by different usage purposes afterwards (drinking water, recreation). Changes in the chironomid succession indicate two main phases. The initial phase, characterized by the extreme scarcity of chironomid remains and low organic matter content, reflected the intense use of the reservoirs as hydro-energy sources for local mining and metallurgy. The second phase reflected more stable hydromorphological conditions and different management regimes after the intense mining pressure ceased. Characteristic features of this phase were a significantly higher abundances and greater diversity in the chironomid assemblages as a response to the higher, more stable water-levels and increased habitat complexity. This high diversity combined with the occurrence of littoral taxa in the most recent sediments indicates increased nutrient concentrations and, in turn, increased macrophyte growth in the littoral. Interestingly, eutrophication seems to have been a natural process and not the effect of increased human influence, since the same trend was also recorded in the reservoir used as a drinking-water source with no direct human influence in its catchment. The results of our study offer greater insight into the effects of dramatic water-level fluctuations on chironomid fauna and form a basis for more appropriate management of these manmade reservoirs which constitute an important part of the historical mining landscape.

\section{ACKNOWLEDGMENTS}

We are grateful to Vaclav Koleda of the Slovak Water Management Enterprise and Daniel Harvan of the Slovak Mining Museum for providing valuable information on the mining history and reservoir management. Thanks are also due to Rasto Milovsky and Juraj Surka of the Earth Science Institute, Slovak Academy of Sciences, for their considerable help with fieldwork. We are grateful to David W. Hardekopf for proof reading and English correction. We also wish to thank to two anonymous reviewers for their valuable comments and suggestions to the previous version of the manuscript.

This research was funded by a grant of the Slovak Scientific Grant Agency, VEGA (1/0664/15).

\section{REFERENCES}

Andersen T, Cranston PS, Epler JH, 2013. The larvae of Chironomidae (Diptera) of the Holarctic Region - Keys and diagnoses. Insect Syst. Evol. Suppl. 66:1-571.

Armitage PD, 1983. Chironomidae from Cow Green reservoir and its environs in the first years of its existence (19701977). Aquat. Insects 5:115-130.

Baxter RM, 1977. Environmental effects of dams and impoundments. Annu. Rev. Ecol. Syst. 8:255-283.

Bell FG, Donnelly LJ, 2006. Mining and its Impact on the Environment. CRC Press: 536 pp.

Bitušík P, Svitok M, Bačík J, 2007. Chironomids (Diptera: Chironomidae) of man-made reservoirs in the Banská Štiavnica mining region (Slovakia). Acta Zool. Univ. Comen. 47:115-126.

Brodersen KP, Lindegaard C, 1999. Classification, assessment 
and trophic reconstruction of Danish lakes using chironomids. Freshwater Biol. 42:143-157.

Brodersen KP, Quinlan R, 2006. Midges as palaeoindicators of lake productivity, eutrophication and hypolimnetic oxygen. Quaternary Sci. Rev. 25:1995-2012.

Brooks SJ, Bennion H, Birks HJB, 2001. Tracing lake trophic history with a chironomid - total phosphorus inference model. Freshwater Biol. 46:513-533.

Brooks SJ, Langdon PG, Heiri O, 2007. The Identification and Use of Palaearctic Chironomidae Larvae in Palaeoecology. QRA Technical Guide No. 10. QRA, London: 276 pp.

Campbell CE, Knoechel R, Copeman D, 1998. Evaluation of factors related to increased zooplankton biomass and altered species composition following impoundment of a Newfoundland reservoir. Can. J. Fish. Aquat. Sci. 55:230-238.

Chernyshev IV, Konečný V, Lexa J, Kovalenker VA, Jeleň S, Lebedev V, Goltsman YV, 2013. K-Ar and Rb-Sr geochronology and evolution of the Štiavnica Stratovolcano (Central Slovakia). Geol. Carpath. 64:327-351.

Fuska J, Kubinský D, Lackóová L, Weis K, 2015. Vindšachta Water Reservoir-Using GIS Tools for a Comparison of Storage Capacity in 1887 and 2014. Kartografija i geoinformacije 14:42-57.

Grimm EC, 1987. CONISS: a FORTRAN 77 program for stratigraphically constrained cluster analysis by the method of incremental sum of squares. Comput. Geosci. 13:13-35.

Heiri O, Lotter AF, Lemcke G, 2001. Loss on ignition as a method for estimating organic and carbonate content in sediments: reproducibility and comparability of results. J. Paleolimnol. 25:101-110.

Jakab Z, 2003. Reconstruction of reservoirs in Banska Stiavnica surrounding since the second half of the $19^{\text {th }}$ century. Spravodaj 43 (2-4):78-87.[Article in Slovak].

Juggins S, 2007. C2: Software for Ecological and Palaeoecological Data Analysis and Visualisation (User Guide Version 1.7.7). Newcastle upon Tyne: Newcastle University, 77. https://www.staffncl.ac.uk/stephen.juggins/software/ C2Home.htm (accessed 01.02.2017).

Konečný V, Lexa J, Halouzka R, Hók J, Vozár J, Dublan L, Nagy A, Šimon L, Havrila M, Ivanička J, Hojstričová V, Mihaliková A, Vozárová A, Konečný P, Kováčiková M, Filo M, Marcin D, Klukanová A, Liščák P, Žáková E, 1998. [Explanatory notes to the geological map of Štiavnické vrchy and Pohronský Inovec mountain ranges (Štiavnica Stratovolcano)].[in Slovak with English summary]. Geol. Surv. Slovak Republic, Bratislava: 473 pp.

Križáni I, Andráš P, Ladomerský J, 2007. [Contamination of Štiavnicé vrchy Mountains by mining activity].[in Slovak with English summary]. Technical University, Zvolen: 100 pp.

Krzyzanek E, 1986. Development and structure of the Goczałkowice reservoir ecosystem. XIV. Zoobenthos. Ekologia Polska 34:491-513.
Kubinský D, Fuska J, Weis K, Lehotský M, Pokrývkový J, 2013. [Changes of the bottom relief and accumulation volume of an artificial water reservoir and intensity of its silting for the last 125 years. Example of Vel'ká Richňava].[Article in Slovak with English summary]. Geomorphologia Slovaca et Bohemica 13:1-40.

Langdon PG, Ruiz Z, Brodersen KP, Foster ID, 2006. Assessing lake eutrophication using chironomids: understanding the nature of community response in different lake types. Freshwater Biol. 51:562-577.

Langdon PG, Ruiz Z, Wynne S, Sayer CD, Davidson TA, 2010. Ecological influences on larval chironomid communities in shallow lakes: implications for palaeolimnological interpretations. Freshwater Biol. 55:531-545.

Lichner M, Kušnierová E, Lichner M, Novák J, Podkonický L, 1999. [Banskoštiavnické tajchy].[Book in Slovak and English].(Banská Štiavnica's Water Reservoirs). Studio Harmony, Banská Bystrica: 126 pp.

Matěna J, 1990. Succesion of Chironomus Meigen species (Diptera, Chironomidae) in newly filled ponds. Int. Rev. Ges. Hydrobiol. 75:45-57.

Moller Pillot HKM, 2009. Chironomidae larvae of the Netherlands and adjacent lowlands. Biology and ecology of the Chironomini. KNNV Publishing, Zeist: 270 pp.

Novák J, 1977. [The water management system in Banská Štiavnica Ore District and its function in the past]. [In Slovak with English summary]. Proceedings of Slovak Mining Museum in Banská Štiavnica 8:109-141.

Prat N, Real M, Rieradevall M, 1992. Benthos of Spanish lakes and reservoirs. Limnetica 8:221-229.

Rybicka EH, 1996. Impact of mining and metallurgical industries on the environment in Poland. Appl. Geochem. 11:3-9.

Smol JP, Birks HJB, Last WM, 2001. Tracking environmental change using lake sediments. Volume 4. Zoological indicators. Kluwer Academic Publishers, Dordrecht: 217 pp.

Szarlowicz K, Reczynski W, Misiak R, Kubica B, 2013. Radionuclides and heavy metal concentrations as complementary tools for studying the impact of industrialization on the environment. J. Radioanal. Nucl. Chem. 298:1323-1333.

Szarlowicz K, Kubica B, 2014. ${ }^{137} \mathrm{Cs}$ and ${ }^{210} \mathrm{~Pb}$ radionuclides in open and closed water ecosystems. J. Radioanal. Nucl. Chem. 299:1321-1328.

Szarlowicz K, Reczynski W, Czajka A, Spyt B, Szacilowski G, 2018. Comprehensive study of the mountainous lake sediments in relation to natural and anthropogenic processes and time (Mały Staw Lake, Poland). Environ. Sci. Pollut. Res. 25:3335-3347.

Teicke DIJ, Tonn DIR, 2006. [Dichtungssanierungen an historischen Erddämmen].[Article in German]. Wasser Wirtschaft 7-8:1-11. 